\title{
A Case of Solitary Fibrous Tumor of Hard Palate
}

\author{
Seung Ho Shin ${ }^{1}$, Min Pyo Hong ${ }^{1,3}$, Yoon Jin Cha ${ }^{2,4}$, and Jae-Yol Lim ${ }^{1,3}$ (D \\ ${ }^{I}$ Departments of Otorhinolaryngology, ${ }^{2}$ Pathology, Yonsei University College of Medicine, Seoul; and \\ ${ }^{3}$ Departments of Otorhinolaryngology, ${ }^{4}$ Pathology, Gangnam Severance Hospital, Yonsei University College of Medicine, Seoul, Korea
}

\author{
경구개에 발생한 고립성 섬유종 1예 \\ 신승호 ${ }^{1} \cdot$ 홍민표 ${ }^{1,3} \cdot$ 차윤진 ${ }^{2,4}$ 임재열 ${ }^{1,3}$ \\ 연세대학교 의과대학 이비인후과학교실, ${ }^{1}$ 병리학교실, ${ }^{2}$ 연세대학교 의과대학 강남세브란스병원 이비인후과학교실, ${ }^{3}$ 병리학교실 ${ }^{4}$
}

\author{
Received October 9, 2017 \\ Revised November 21, 2017 \\ Accepted November 22, 2017 \\ Address for correspondence \\ Jae-Yol Lim, MD, PhD \\ Department of Otorhinolaryngology, \\ Gangnam Sevrance Hospital, \\ Yonsei University \\ College of Medicine, 211 Eonju-ro, \\ Gangnam-gu, Seoul 06273, Korea \\ Tel $+82-2-2019-3468$ \\ Fax $+82-2-3463-4750$ \\ E-mail jylimmd@yuhs.ac
}

Solitary fibrous tumor (SFT) is a rare mesenchymal neoplasm first described and often encountered in the pleura. It has also been documented in a variety of extrapleural sites including the abdominal cavity, respiratory tract, lung, breast, and rarely in the head and neck region. SFT in the hard palate is an extremely unusual location. We present a rare case of SFT that presented as a palate mass, which was suggested as a mesenchymal cell neoplasm by preoperative punch biopsy, and finally diagnosed as STF after successful surgical excision. SFTs should be considered as a differential diagnosis of palate benign tumor when preoperative pathologic findings show mesenchymal neoplasms of fibroblastic or myofibroblastic origin. Possible malignant variants should be distinguished by evaluating the histological parameters, including high cellularity, frequent mitotic activity, nuclear pleomorphism, and presence of necrosis.

Korean J Otorhinolaryngol-Head Neck Surg 2019;62(4):238-41

Key Words Hard palate - Soft tissue tumor - Solitary fibrous tumor.

\section{서 론}

고립성 섬유종(solitary fibrous tumor)은 1931년 Klemperer 와 $\mathrm{Rabin}^{1)}$ 에 의해 처음으로 기술된 양성 방추세포 종양으로 주로 흉막에서 기원하며 복강, 상기도, 폐, 유방, 안와 척추 및 체성 연부조직 등 흥막 외 위치에서도 발생한다. ${ }^{2)}$ 두경부 영역에서는 아주 드물게 발생하는데 구강, 부비강, 비인두, 주 타액선, 갑상선 등에서 보고되었다. ${ }^{3)}$ 구강 내에서는 협부 점 막에서 가장 흔하게 보고되었으며 혀, 치은, 구개, 입술 등에 서 발생한다. 이 중 경구개에 발생한 고립성 섬유종은 전 세 계적으로 매우 드물며, 국내에서는 아직 보고된 바가 없다.)

저자들은 경구개 종물로 내원하여 수술적 절제를 통해 진 단 및 치료한 고립성 섬유종 1 예를 경험하였기에 문헌 고찰

This is an Open Access article distributed under the terms of the Creative Commons Attribution Non-Commercial License (http://creativecommons.org/licenses/by-nc/4.0) which permits unrestricted non-commercial use, distribution, and reproduction in any medium, provided the original work is properly cited.
과 함께 보고하는 바이다.

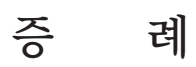

49세 여자 환자가 1달 전부터 크기가 증가하는 경구개 종물 로 인한 불편감 및 구음장애로 내원하였다. 과거력상 특이 사항은 없었으며 내원 당시 시행한 이학적 검사상 경구개에 $3 \times 4 \mathrm{~cm}$ 정도의 무통성 종괴가 관찰되었다. 종괴는 비교적 단 단하였고 경계가 분명하였으나 구개에 고착된 소견을 보였다.

수술 전 병변 부위에서 생검을 시행한 결과 간엽성 종양으 로 보고되었다. 전산화단층촬영에서 조영 증강을 보이는 경계 가 명확한 종양이 관찰되었으며, 상악동 아래벽으로 골 소실 이 관찰되었다(Fig. 1).

수술소견상 경구개에 $3 \times 4 \mathrm{~cm}$ 크기의 단단한 고형 종괴가 관찰되어(Fig. 2), 전신마취하 복와위 상태에서 경구강 접근 법으로 제거하였다. 일측 대구개동맥을 결찰하였고 구개 점 
막을 포함하여 종물을 일괴로 제거하였다. 상악동 아래벽으 로 골파괴가 진행된 부분은 드릴로 제거하여 절제연을 유지 하였다. 종양을 제거한 결손 부위에는 남은 구개점막을 이용 한 회전피판술(palatal rotation flap)로 재건하였고 노출된 경구개 부에 인조 진피로 일차 봉합하여 구강 점막 재생 기 간 동안 불편감을 줄이고자 하였다.

육안 소견상 종괴는 피막은 없으나 비교적 경계가 분명하 였으며 구개 부착 부위는 일부 분절되었지만 완전 절제된 형 태로 사료되었다. 현미경적 검사상 내부는 중중도 이상의 세포 밀도를 보였다. 고배율 현미경 소견상 방추형 세포(spindle cell) 로 구성된 병변은 불규칙한 세포 배열 및 특징적인 사슴뿔 모 양의 혈관으로 구성되어 있었다(Fig. 3). 면역조직화학염색(im-
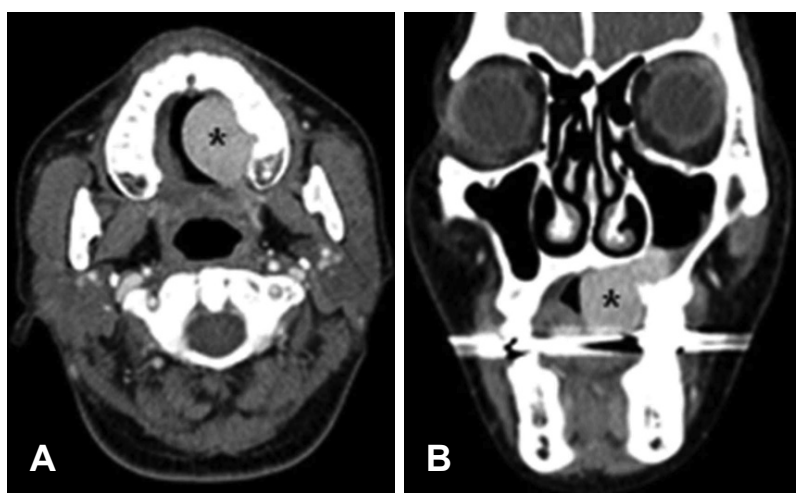

Fig. 1. Preoperative axial (A) and coronal (B) computed tomography findings. A $3.4 \times 2.8 \times 3.7 \mathrm{~cm}$ well enhancing mass (asterisk) probably originating from left side hard palate with bony erosion at inferomedial wall of left maxillary sinus. munohistochemical stain)상 종양세포는 CD34에 부분적으 로 양성을 보였고, STAT6는 거의 모든 종양세포의 핵에서 발 현되었다.

환자는 수술 후 5일째 합병증 없이 퇴원하였으나 퇴원 1주 일 후 접합부가 벌어져 볼근점막피판술(buccinators myomucosal flap)을 시행하여 결손 부위를 추가로 재건하였다. 이 후 특별한 합병증이나 재발 소견 없이 추적관찰 중이다.

\section{고 찰}

고립성 섬유종은 흥막의 간엽세포에서 기원하는 드문 양성 종양으로 두경부에서는 1991년 Witkin과 Rosai'가가 처음 보 고 하였다. 흥막 외에서 발생한 고립성 섬유종은 전체 증례 의 $30 \%$ 이며, 그 중에서 두경부는 $6 \%$ 정도로 드물게 보고 되 고 있다. ${ }^{6}$ 이중 경구개에서 발생하는 경우는 매우 드물다.

Shimoyama 등 ${ }^{4}$ 은 구강에서 발생한 고립성 섬유종 48예를 모아 분석하였다. 여성에서 더 많았으며(여자 30명, 남자 18명), 주로 성인(평균 51.3세)에서 나타났다. 구강에서는 협부점막 에서 가장 많이 발생하였으며 혀, 치은, 연구개, 입술 순으로 나타났다. 고립성 섬유종은 대부분 성장이 느리고 경계가 분 명하며 증상이 없으나 두경부의 경우 해부학적 위치에 따라 연하곤란, 구음장애, 저작 이상, 비폐색 등 다양한 임상 증상 을 동반한다.

영상검사에서 진단에 특징적인 소견은 없으나 자기공명영 상의 T1-강조영상에서는 명확한 경계를 보이는 종물이 동등

Fig. 2. Intraoperative view shows a firm, well-defined mass on the hard palate $(A)$. The gross specimen shows well circumscribed, nonencapsulated mass with white, firm cut surface (B). Intraoperative surgical view after extirpation of tumor from palate $(C)$. A picture of postoperative surgical site at 2 months follow-up (D).
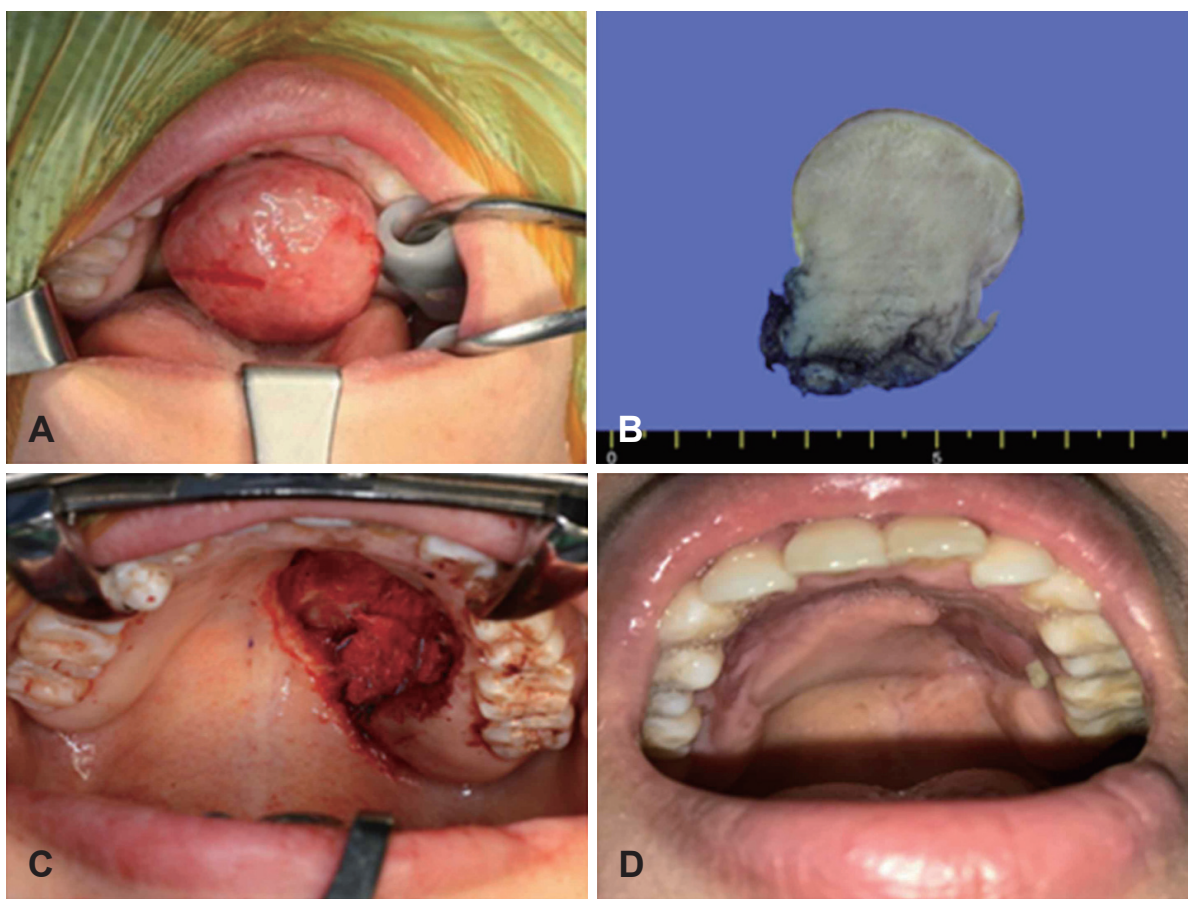


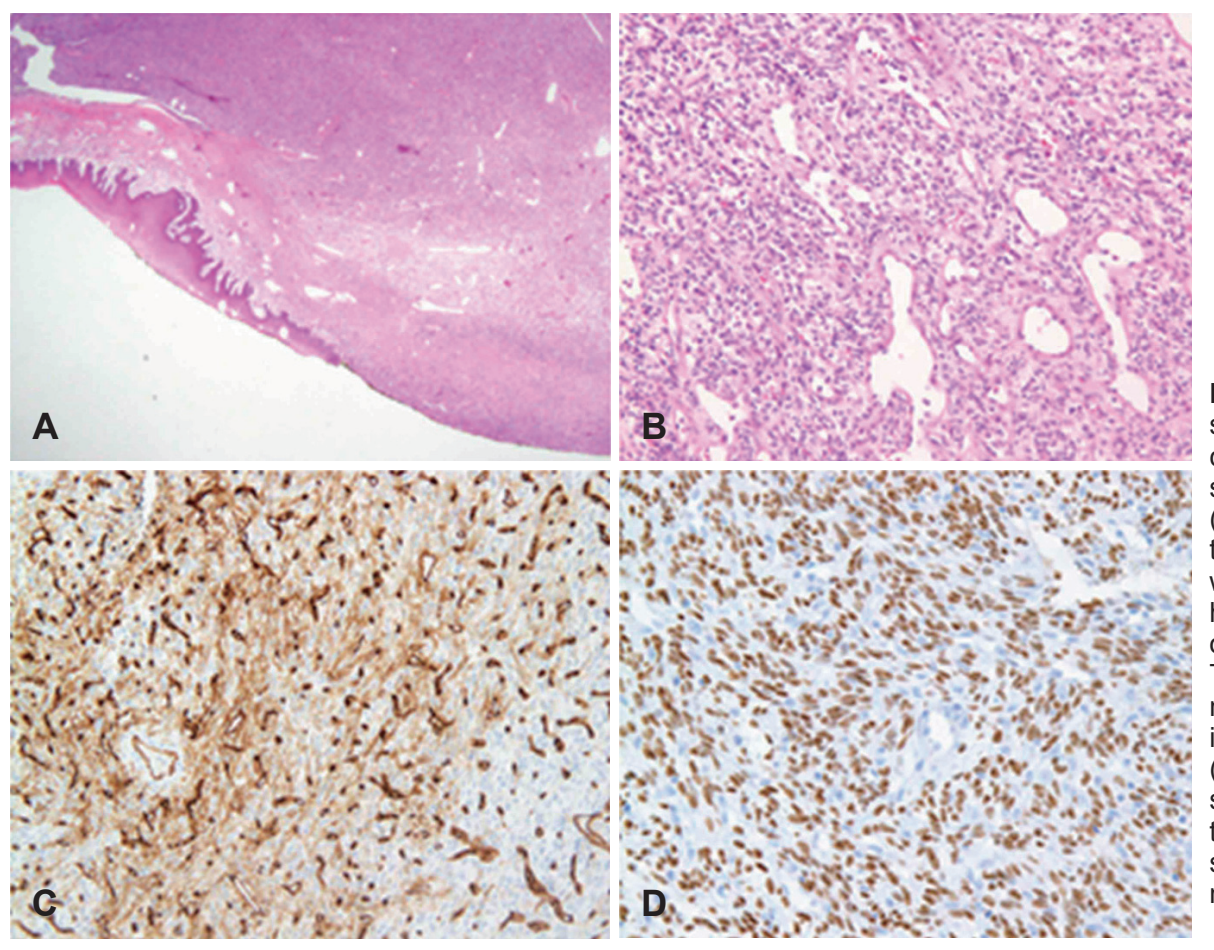

Fig. 3. Pathologic findings of the resected tumor. IIl-defined infiltrative cellular lesion (hematoxylin and eosin, original magnification $\times 12.5$ ) (A). Hypercellular area shows patternless architecture of spindle cells with mild nuclear atypia. Note staghorn vessels (hematoxylin and eosin, original magnification $\times 200$ ) $(B)$. The tumor cells demonstrate immunoreactivity for CD34 (immunochemistry, original magnification $\times 200$ ) (C). The tumor cells demonstrate strong nuclear labeling for STAT6, the confirmative marker for diagnosis of solitary fibrous tumor (immunochemistry, original magnification $\times 400)(D)$.

신호강도로 보이거나 저강도 신호로 나타난다. T2-강조영상, 특히 가돌리늄 조영증강 영상에서 저신호강도 및 고신호강 도로 불규칙한 배열을 보이며, 비균질한 조영 증가를 보인다. 전산화단층촬영 영상에서는 저음영 종물로 보이며, 조영 증강 된 전산화단층촬영에서는 불균일하게 조영 증강되는 영상을 보이며, 종괴의 압력으로 인한 골파괴 소견이 보이기도 한다.")

1997년 Chan ${ }^{8}$ 은 고립성 섬유종의 진단 기준을 제안하였 다. 고립성 섬유종은 조직학적으로 특징적인 방추세포와 교원 질이 불규칙하게 배열된 부분이 있으며, 주변 조직과 경계가 명확히 나누어져 있다. 면역조직화학염색에서 특징적으로 $\mathrm{CD} 34$ 항원의 양성반응을 보인다. 그외에도 Bcl-2, CD99 등 에서 양성반응을 보이고, desmin, cytokeatin, S-100 protein, $\mathrm{HMB}-45$ 에는 음성반응 혹은 약양성 반응을 보인다. 하지만 이런 조직소견은 다양한 형태로 나타나므로 다른 연부조직 종양과의 감별이 쉽지 않다. 2013년 고립성 섬유종의 NAB2/ STAT6 유전자융합특성이 발견되면서 STAT6 면역조직화학 염색의 핵 양성인 경우를 현재 진단 기준으로 사용한다. ${ }^{9}$ 본 증례에서도 CD34와 STAT6 염색에 양성을 보였다.

고립성 섬유종은 대부분 양성지만 악성 양상을 나타내는 경우도 보고 되었다. 흉막에서 발생한 경우는 5 20\%에서 악 성 경과를 보이는 것으로 알려져 있고, 흉막 이외의 위치에서 는 악성의 경우는 드물지만 재발도 가능한 것으로 알려져 있 다. ${ }^{10)} \mathrm{Chan}^{8)}$ 은 악성화를 나타내는 조직소견으로 높은 세포 밀 도, 세포의 다형태성, 유사분열 수의 증가 $>4$ mitoses/10 high power field)를 제시했고, 이와 더불어 침윤성 경계, 출혈, 괴 사도 악성을 시사하는 조직소견에 포함된다. ${ }^{2)}$ 임상적으로는 종물의 크기가 커질수록, 발병기간이 길수록, 재발이나 악성 의 가능성이 높다. ${ }^{7)}$

고립성 섬유종의 치료는 종양을 완전히 절제하는 것이다. 불 완전 절제를 시행한 경우에는 재발 및 악성의 가능성이 높아 지게 되므로 가능하면 완전 절제를 하고, 불완전하게 제거할 때는 수술 후 방사선치료를 병행하여 재발을 줄일 수 있다. ${ }^{7)}$ 전신 항암요법의 효과에 대해서는 아직 논란이 많다. ${ }^{11)}$ 고립성 섬유종은 혈관이 풍부한 종양이므로 절제 시 출혈이 심할 것 이라 생각이 되면 출혈을 감소시키기 위해 혈관색전술을 시행 하여 수술 중 출혈을 줄일 수 있다. ${ }^{12)}$ 수술적 절제 후 6년 후 까지 재발이 보고되었다고 알려져 있어, 장기간 추적관찰이 필요할 것으로 생각된다. ${ }^{7)}$

현재까지 경구개에서 발생한 고립성 섬유종은 본 증례를 포함하여 매우 드물어 질병의 특성을 논하기는 어렵다.) 다만 흥막외 고립성 섬유종의 특성을 고려할 때 수술로 완전 절제 가 가능했다면 방사선치료 등의 추가치료는 필요하지 않을 것 으로 생각되나 낮은 빈도지만 재발이 가능한 것으로 알려져 있어 재발을 확인하기 위한 장기적인 추적관찰이 필요하다.

구개내 종물로 발생한 경우에는 타액선 종양, 신경초종, 섬 유종 등과 같은 구강내 발생 가능한 종양과의 감별이 필요하 며, 형태학적 특성이 다양하여 혈관주위세포종(hemangiopericytoma), 경초종양(nerve sheath tumor), 섬유형성이상 
(fibrous histiocytoma), 섬유육종(firosarcoma), 평활근육종 (leiomyosarcoma), 윤활막육종(synovial sarcoma)등과의 조직학적 감별이 필요하다. ${ }^{13)}$ 조직 생검을 통해 감별진단에 도 움이 될 수 있으며 특히 간엽성 종양의 특성을 보이는 경우 고 립성 섬유종을 감별 진단으로 고려해야 한다.

\section{ORCID}

Jae-Yol Lim

https://orcid.org/0000-0002-9757-6414

\section{REFERENCES}

1) Klemperer P, Rabin CB. Primary neoplasms of the pleura. A report of five cases. Arch Pathol 1931;11:385-412.

2) Daigeler A, Lehnhardt M, Langer S, Steinstraesser L, Steinau HU, Mentzel T, et al. Clinicopathological findings in a case series of extrathoracic solitary fibrous tumors of soft tissues. BMC Surg 2006; 6:10.

3) Ganly I, Patel SG, Stambuk HE, Coleman M, Ghossein R, Carlson $\mathrm{D}$, et al. Solitary fibrous tumors of the head and neck: a clinicopathologic and radiologic review. Arch Otolaryngol Head Neck Surg 2006;132 (5):517-25.

4) Shimoyama T, Horie N, Ide F. Solitary fibrous tumor of the palate: a case report and review of the literature. J Oral Maxillofac Surg 2004; 62(7):895-7.
5) Witkin GB, Rosai J. Solitary fibrous tumor of the upper respiratory tract. A report of six cases. Am J Surg Pathol 1991;15(9):842-8.

6) Gold JS, Antonescu CR, Hajdu C, Ferrone CR, Hussain M, Lewis JJ, et al. Clinicopathologic correlates of solitary fibrous tumors. Cancer 2002;94(4):1057-68.

7) Cox DP, Daniels T, Jordan RC. Solitary fibrous tumor of the head and neck. Oral Surg Oral Med Oral Pathol Oral Radiol Endod 2010;110 (1):79-84.

8) Chan JK. Solitary fibrous tumour--everywhere, and a diagnosis in vogue. Histopathology 1997;31(6):568-76.

9) Robinson DR, Wu YM, Kalyana-Sundaram S, Cao X, Lonigro RJ, Sung YS, et al. Identification of recurrent NAB2-STAT6 gene fusions in solitary fibrous tumor by integrative sequencing. Nat Genet 2013; 45(2): $180-5$

10) Kim HY, Lee SY, Kang SJ, Kim HJ. Solitary fibrous tumor of the orbit: a poorly-recognized orbital lesion. Acta Ophthalmol Scand 1999;77(6):704-8.

11) Zuniga MG, Orr BA, Chang SS, Tufano RP. Suboccipital malignant solitary fibrous tumor: report of a case. Ear Nose Throat J 2012;91(2): E25-7.

12) Ahn TJ, Bae WY, Kim SJ, Kang MJ. Solitary fibrous tumor in nasal cavity: surgical treatment after angiographic embolization. Korean J Otorhinolaryngol-Head Neck Surg 2009;52(3):258-61.

13) Vimi S, Punnya VA, Kaveri H, Rekha K. An aggressive solitary fibrous tumor with evidence of malignancy: a rare case report. Head Neck Pathol 2008;2(3):236-41. 